\title{
Economic Returns Using Risk-rated Budget Analysis for Rabbiteye Blueberry in Georgia
}

\author{
Esendugue Greg Fonsah ${ }^{1,5}$, Gerard Krewer ${ }^{2}$, \\ Kerry Harrison ${ }^{3}$, and Danny Stanaland ${ }^{4}$
}

ADDITIONAL INDEX WORDs. risk-rated returns, production cost, harvesting, marketing, variable costs, fixed costs

\begin{abstract}
SUMmary. Rabbiteye blueberry (Vaccinium ashei) is the most important type of blueberry grown in Georgia. This species is classified as a highbush blueberry type, but is distinctively different from highbush blueberry ( V. corymbosum) in its ability to withstand high temperatures and low-organic-matter soils. However, rabbiteye blueberries, like other fruit crops, are subject to price and yield fluctuation. These volatilities depend on several factors, including the cultivar produced and sold, locality, aggregate productivity, targeted market, and timing. As a result, profit margin is hard to determine. The objective of this study was to estimate economic returns using risk-rated budget analysis for rabbiteye blueberry under Georgia conditions. The first-year establishment and maintenance cost of growing rabbiteye blueberry in Georgia was estimated at \$5022.04/acre. Total harvesting and marketing cost in the second year was $\$ 719.44$ /acre. In the third year, total variable and fixed cost was $\$ 3487.50 /$ acre. In the full production year (fourth year), the cost was estimated at $\$ 4671.17 /$ acre. The compounded and recaptured establishment annual cost was $\$ 2736.11 /$ acre. The risk-rated expected returns over total costs $63 \%$ of the time were $\$ 679.00 /$ acre. The chances of making a profit were $77 \%$ and the base budgeted net revenue was $\$ 369.00 /$ acre. The total budgeted cost was $\$ 0.94 / 1 b$. The estimated annual total fixed machinery cost was $\$ 698.00 /$ acre. The total annual cost of drip irrigation was $\$ 161.15 /$ acre.
\end{abstract}

$\mathrm{R}$ abbiteye blueberry is the most important blueberry grown in Georgia. An estimated 4.95\% of the 6003 acres of blueberries grown in Georgia are rabbiteye blueberry (Florkowski, 2004). This species is classified as a highbush blueberry type, but is distinctively different from highbush blueberry in its ability to withstand high temperatures and lower organic matter soils. Rabbiteye blueberry is relatively high yielding, with commercial yields in the range of 5000 to $8000 \mathrm{lb} /$ acre typical on well-maintained fields. Occasionally, yields in excess of 10,000 lb/acre are

We are indebted to the Southern Small Fruits Consortium for providing funding for this study. We are equally grateful to G. Westberry, W.O. Mizelle, B. Celine, M. Mainland, B. Lisec, T. Cross, and B. Strik for whom their work was used as a starting point for developing this research. We also express our gratitude to Alice H. Pitts who helped with all the formatting, word processing, and tables for this work.

${ }^{1}$ Assistant Professor, Department of Agriculture and Applied Economics, University of Georgia, Tifton, GA 31793

${ }^{2}$ Professor, Department of Horticulture, University of Georgia, Tifton, GA 31793

${ }^{3}$ Biological and Agricultural Engineering Department, University of Georgia, Tifton, GA 31793

${ }^{4}$ County Agent, Clinch County Extension Service, University of Georgia, Homerville, GA 31634

${ }^{5}$ Corresponding author. E-mail: gfonsah@uga.edu. reported. Fields may remain productive for 30 years or more.

The fruit is sweet, with excellent firmness and shelf life. Ripening in southern Georgia begins in late May (hand harvest) for some cultivars, but heavy-machine harvest does not begin until the first week of June. Because heavy rains often begin falling in lower-southern Georgia by mid-June, much of the rabbiteye blueberry crop is machine harvested for the processed market in wet years.

Cultural requirements for rabbiteye blueberry are less exacting than highbush blueberry (Krewer and NeSmith, 2002; Smith, 2003; Payne et al. 1993). The bushes grow well in many types of sandy clay loam, loam, loamy sand, and sand soil series if the soil chemistry and soil preparation is correct. Unless a large amount of acidic organic matter is added to the soil, growth usually is much better in virgin soils than in soils previously farmed. Many virgin soils in Georgia have an organic matter content of $2 \%$ or more. This represents about $20,000 \mathrm{lb} /$ acre of organic matter. Organic matter should be added to the planting hole or bed on sites with less than $2 \%$ organic matter to help get the bushes off to a good start. Normally, milled pine bark or peatmoss is used. Blueberries also respond very well to mulching with acidic materials such as pine bark, pine straw, and pine sawdust. Mulching provides significant weed control and increases the effective root zone as the mulch decomposes. Small grain straws and yard waste also can be used, but have a higher $\mathrm{pH}$.

Land clearing is major expense in blueberry production. Normally, merchantable timber is cut, and stumps are removed, followed by bulldozing with a root rake blade to leave the topsoil behind. Multiple harrowings followed by land leveling to remove small low pockets is required. Large roots are picked up, but small roots and sticks should be left to add organic matter. On wet sites, beds are formed by using a pine tree bedder. The beds are then widened by using a fire break plow or the front gangs of a wood harrow.

Soil $\mathrm{pH}$ should be adjusted (if needed) to 4.0 to 5.3 on sandy soils and to 4.5 to 5.3 on clay soils 6 months before planting (Steck and Payne, 1993). Sites that have over $900 \mathrm{lb} /$ acre of calcium and very high levels of phosphorus $(300 \mathrm{lb} /$ acre $)$ are less suitable for rabbiteye blueberry. However, if phosphorus levels are very low, phosphorus should be incorporated before planting.

Although rabbiteye blueberry responds well to overhead irrigation

\begin{tabular}{llll}
\hline $\begin{array}{l}\text { Units } \\
\text { To convert U.S. to SI, } \\
\text { multiply by }\end{array}$ & U.S unit & SI unit & $\begin{array}{l}\text { To convert SI to U.S., } \\
\text { multiply by }\end{array}$ \\
\hline 0.4047 & acre $(\mathrm{s})$ & $\mathrm{ha}$ & 2.4711 \\
0.3048 & $\mathrm{ft}$ & $\mathrm{m}$ & 3.2808 \\
3.7854 & $\mathrm{gal}$ & $\mathrm{L}$ & 0.2642 \\
9.3540 & gal/acre & $\mathrm{L} \cdot \mathrm{ha}^{-1}$ & 0.1069 \\
0.7457 & horsepower & $\mathrm{kW}$ & 1.3410 \\
2.54 & inch(es) & $\mathrm{cm}$ & 0.3937 \\
0.4536 & lb & $\mathrm{kg}$ & 2.2046 \\
1.1209 & lb/acre & $\mathrm{kg} \cdot \mathrm{ha}^{-1}$ & 0.8922 \\
0.7646 & yard & $\mathrm{m}^{3}$ & 1.3080
\end{tabular}


for freeze protection, typically, drip irrigation is used for rabbiteye blueberry production because of lower cost. Normally, systems are set up to provide a maximum of 2500 to 3000 gal/acre per day during the hottest, driest time of the year. In some areas of southeastern Georgia near the Atlantic coast, there are restrictions on the size of wells allowed (maximum $100,000 \mathrm{gal} / \mathrm{d}$ ). In this case, a series of 4 -inch-diameter wells or filtered surface water may be used instead of a 6- or 8-inch-diameter well.

Growers vary in the type of plants set. Generally l-gal-size plants are recommended for new growers because weeds can rapidly overgrow smaller plants. However, the use of smaller size plants can offer a significant cost savings in the year of establishment. Many of the newer cultivars have a royalty of $\$ 0.25 /$ plant, adding about $\$ 150.00 /$ acre to the cost of establishment.

Blueberry is a salt-sensitive plant, but responds well to fertilization. The best results have occurred with a minimum of four fertilizations per year on young plants or one or two applications of slow-release fertilizer per year. Bearing bushes are normally fertilized two or three times per year.

Weed control is a major headache and expense in blueberry production. Much of the rapid growth in a rabbiteye blueberry plant comes from canes that emerge from below ground level or from canes sprouting from renewal pruning cuts. Because these green canes are very sensitive to herbicides, weed control in blueberry is much more difficult than in most fruit crops. Generally, a pre-emergent herbicide is applied in early spring and midsummer. Shielded sprayer or hand-wand applications are needed four to eight times per year, depending on the situation.

Insect and disease control in blueberry can be minimal or extensive, depending on the situation. Many growers are spraying for flea beetle (Altica sylvia) and thrips (Frankliniella vacciaii) most years. Some growers are spraying for blueberry maggot fly (Rhagoletis mendax). Sprays for mummy berry (Monilinia vacciniicorymbosi) and botrytis (Botrytis cinera) are needed in most commercial fields in most years. Many growers are also applying two to three sprays for leaf spot (Septoria albopuncata, Colletotrichum glocogsocioides, and Gloeosporium minus) each year.

\section{Materials and methods}

Rabbiteye blueberry and southern highbush blueberry budgets developed by Westberry et al. (1995), Cline and Mainland (1999), and Lisec et al. (1995) were used as a starting point for developing this budget. Several farm visits and interviews with growers were conducted to study blueberry operations and to collect the necessary primary data needed to estimate cost of production and to obtain information into the type and cost of current practices in southern highbush blueberry culture. Several specialists, extension agricultural economists, horticulturists, agricultural engineers, and county extension agents were visited and interviewed to gather agronomic, irrigation, and equipment data required for this estimate. Vendors of agricultural inputs (fertilizers, chemicals, and equipment) were contacted to obtain the current prices needed to generate variable and the fixed costs components concomitantly. U.S. Department of Agriculture, Economic Research Service publications, and other published resources were consulted to obtain historical information on productivity, marketing, price, and overall outlook of blueberry (Abbe and Messer, 2004; Pollack and Perez, 2003). The objective of this research was to calculate economic returns using risk-rated budget analysis.

Expected returns were computed using a risk-rated method. The risk-rated method assigns five

Table 1. Estimated annual total fixed machinery cost for producing rabbiteye blueberries in Georgia using $7 \%$ interest rate in 2005 .

\begin{tabular}{|c|c|c|c|c|c|c|c|c|}
\hline Item & $\begin{array}{l}\text { Use for this } \\
\text { crop (\%) }\end{array}$ & $\begin{array}{l}\text { Purchase } \\
\text { price }(\$)^{\mathrm{z}}\end{array}$ & $\begin{array}{c}\text { Salvage } \\
\text { value (\$) }\end{array}$ & $\begin{array}{l}\text { Life } \\
(\mathrm{yr})\end{array}$ & $\begin{array}{c}\text { Depreciation } \\
(\$)\end{array}$ & $\begin{array}{c}\text { Interest } \\
(\$)\end{array}$ & $\begin{array}{c}\text { Taxes and } \\
\text { insurance }(\$)\end{array}$ & $\begin{array}{l}\text { Fixed cost } \\
(\$ / \text { acre })^{y}\end{array}$ \\
\hline Sprayer, herbicide & 100 & 600 & 120 & 5 & 96 & 25 & 5 & 5.05 \\
\hline \multicolumn{9}{|l|}{ Rotary mower, $6 \mathrm{ft}$} \\
\hline$(1.8 \mathrm{~m})$ diameter & 100 & 1,400 & 280 & 7 & 160 & 59 & 12 & 9.22 \\
\hline Equipment trailer & 100 & 18,000 & 500 & 20 & 875 & 648 & 130 & 66.08 \\
\hline $\begin{array}{l}\text { Hedger } \\
\text { Hed }\end{array}$ & 100 & 9,000 & 1,800 & 10 & 720 & $\begin{array}{r}1,050 \\
378\end{array}$ & $\begin{array}{r}210 \\
76\end{array}$ & 46.94 \\
\hline Equipment truck & 100 & 20,000 & 4,000 & 5 & 3,200 & 840 & 168 & 168.32 \\
\hline Fertilizer spreader & 100 & 1,500 & 300 & 7 & 171 & 63 & 13 & 9.88 \\
\hline Harvester & 100 & 22,000 & 4,400 & 5 & 3,520 & 924 & 185 & 185.15 \\
\hline Lug carts, four & 100 & 2,600 & 520 & 5 & 416 & 109 & 22 & 21.88 \\
\hline Total investment & & 112,150 & 19,330 & & 11,918 & 4,602 & 920 & 698.00 \\
\hline Total fixed costs & & & & & & & & $17,440.00$ \\
\hline
\end{tabular}

${ }^{2}$ These prices were for new equipment except for the four golf carts; used equipment could be purchased at a reduced cost.

yTotals may not add up because of a rounding error; $\$ 1.00 /$ acre $=\$ 2.4711 / \mathrm{ha}$. 
categories of yield and price per pound of rabbiteye blueberry, thus the use of "best," "optimistic," "median," "pessimistic," and "worst." Risk-rated returns over total costs was calculated by assigning probabilities or chances of occurrences to each of the categories (Brigham, 1982; Fonsah et al., 2007). The percentage chances of profit and the base budgeted net revenue were then calculated. Furthermore, all variable costs components such as preplant, pre-emergence weed control, planting, transplanter, land-preparation, pest and disease control, and fixed cost components such as machinery, irrigation, recaptured establishment costs, overhead, and management were captured. Variable costs included preharvest, harvesting, and marketing costs. Fixed costs included machinery, irrigation, recaptured establishment costs, overhead, and management. Because of the differences in the cost of land in southern Georgia, we intentionally excluded cost of land in our computation even though this is an opportunity cost accrued by the grower (Fonsah et al., 2007).

Assumptions. The risk-rated economic return assumed five different yields and prices per pound at the top of the budget, namely: "best," "optimistic," "median," "pessimistic," and "worst." The "best" and

Table 2. Recapture establishment cost per acre of producing rabbiteye blueberries in Georgia compounded for 20 years at $7 \%$ interest rate.

\begin{tabular}{lccr}
\hline $\begin{array}{l}\text { Time to } \\
\text { production }(\mathbf{y r})\end{array}$ & $\begin{array}{c}\text { Compounded interest } \\
\text { rate }(\%)\end{array}$ & $\begin{array}{c}\text { Pre-establishment } \\
\text { costs }(\$)\end{array}$ & Total $(\$)^{\mathbf{z}}$ \\
\hline 4 & 1.31 & $5,022.04$ & $6,582.88$ \\
3 & 1.23 & $1,498.18$ & $1,835.34$ \\
2 & 1.14 & $1,621.35$ & $1,856.28$ \\
1 & 1.07 & 283.66 & 303.52 \\
Compounded establishment cost & & $10,578.02$ \\
Recaptured annual establishment cost $(\$ / \text { acre })^{\mathrm{y}}$ & & $2,736.11$ \\
\hline
\end{tabular}

${ }^{2}$ Totals may not add up because of a rounding error.

y $\$ 1.00 /$ acre $=\$ 2.4711 /$ ha.

"worst" yield or price levels were expected to occur once in at least 10 years. The "median" yield and price level were expected $63 \%$ of the time. The "optimistic" level would be surpassed about 1 year in 6 years, and the "pessimistic" level would occur 1 year in 6 years.

The fourth year was assumed to be in full production. Plant spacing was $5 \times 12 \mathrm{ft}$. Variable interest rates of $7 \%$ of total operating/variable costs were used for each year. Cost/flat was based on custom packaging. Hiredused labor was contracted at a flat rate of $\$ 10.00 / \mathrm{h}$. The brokerage fee was $15 \%$, but it included cooling and handling. The overhead and management fee was $15 \%$ of the total operating/variable cost. Compounded recaptured costs were based on a $7 \%$ fixed interest rate and the expected life-span of the farm under Georgia conditions was 20 years. Machinery and equipment operation costs calculations were estimated on 50 acres because growers with a smaller farm size would not invest in this type of equipment and machinery. The fixed interest rate used was 7\%.

All of the computations included such items as percentage use for crop, purchase price, salvage value, life

Table 3. Estimated cost per acre of drip irrigation for producing rabbiteye blueberries in Georgia based on 25 acres (10.1 ha) with 12 - $\mathrm{ft}(3.7 \mathrm{~m})$ spacing and a 20 -horsepower $(14.9 \mathrm{~kW})$ electric motor in 2005.

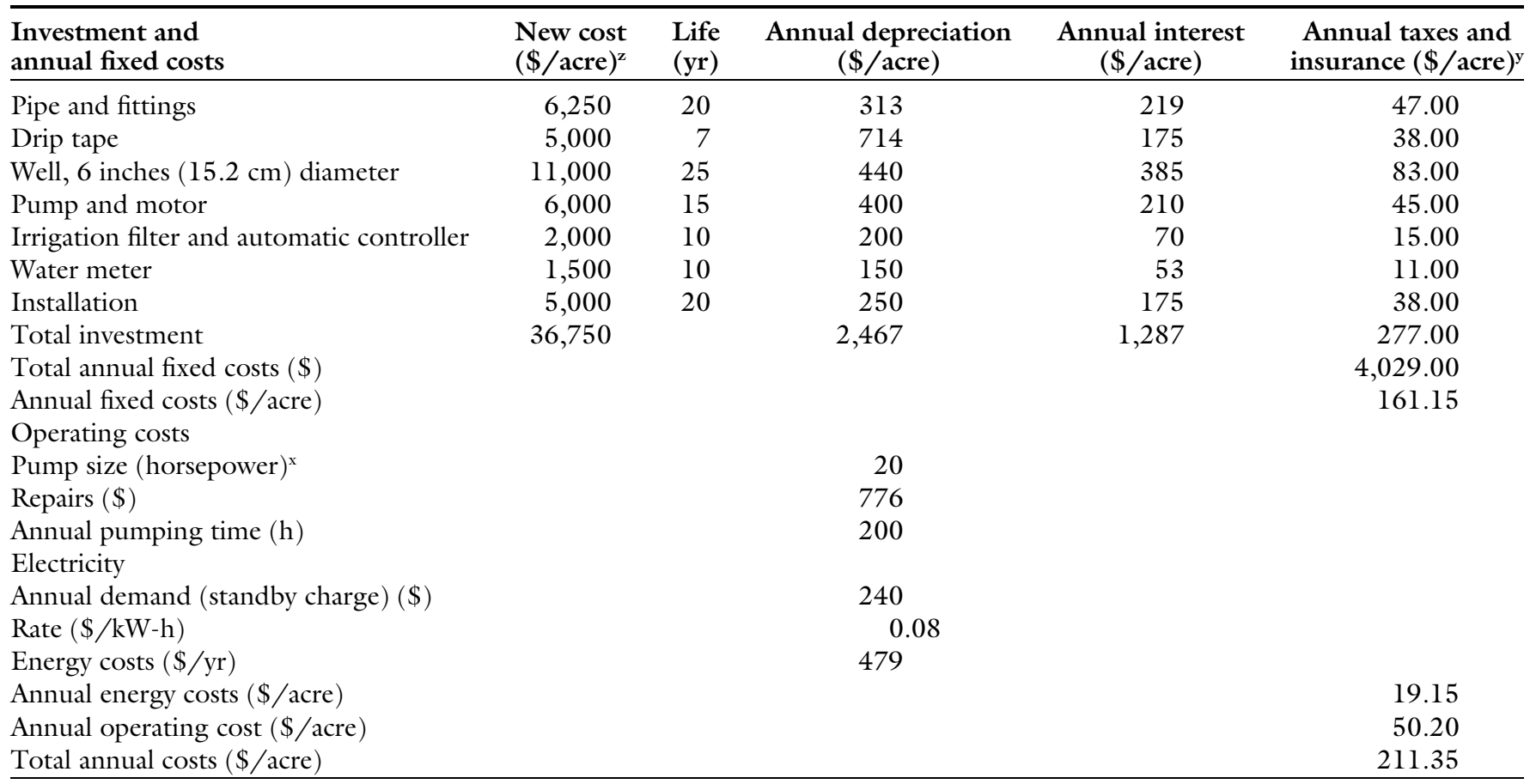

${ }^{\mathrm{z}} \$ 1.00 /$ acre $=\$ 2.4711 / \mathrm{ha}$.

yTotals may not add up because of rounding errors.

${ }^{\mathrm{x}} 1$ horsepower $=0.7457 \mathrm{~kW}$. 
span, depreciation, interest, tax, and insurance. All equipment was assumed to be new. Drip irrigation was calculated based on 25 acres because that was the average farm size for new entrants. The drip line spacing was $12 \times 45 \mathrm{ft}$, and had a 6-inchdiameter well capable of pumping about $300 \mathrm{gal} / \mathrm{min}$. Risk-rated marketing prices and yields were obtained from growers and from Michigan
Blueberry Growers Marketing (Grand Junction, MI). Input and equipment prices were obtained from vendor and machinery dealers, respectively. The adopted variable interest rates for operating/variable costs were for short-term loans. The fixed interest rates used for fixed, machinery, and compounded establishment costs were for long-term loans.
FARM INPUT PRICES. There were several factors that could influence the price of inputs, the total cost of production, and profit margin. Many farmers in Georgia need not invest in drip irrigation materials or dig a new well because they already had them available. If so, that would significantly increase profitability. Also, motor sizes of the drip irrigation were different depending on acreage.

Table 4. Estimated first-year establishment and maintenance cost of producing rabbiteye blueberries in Georgia in 2005.

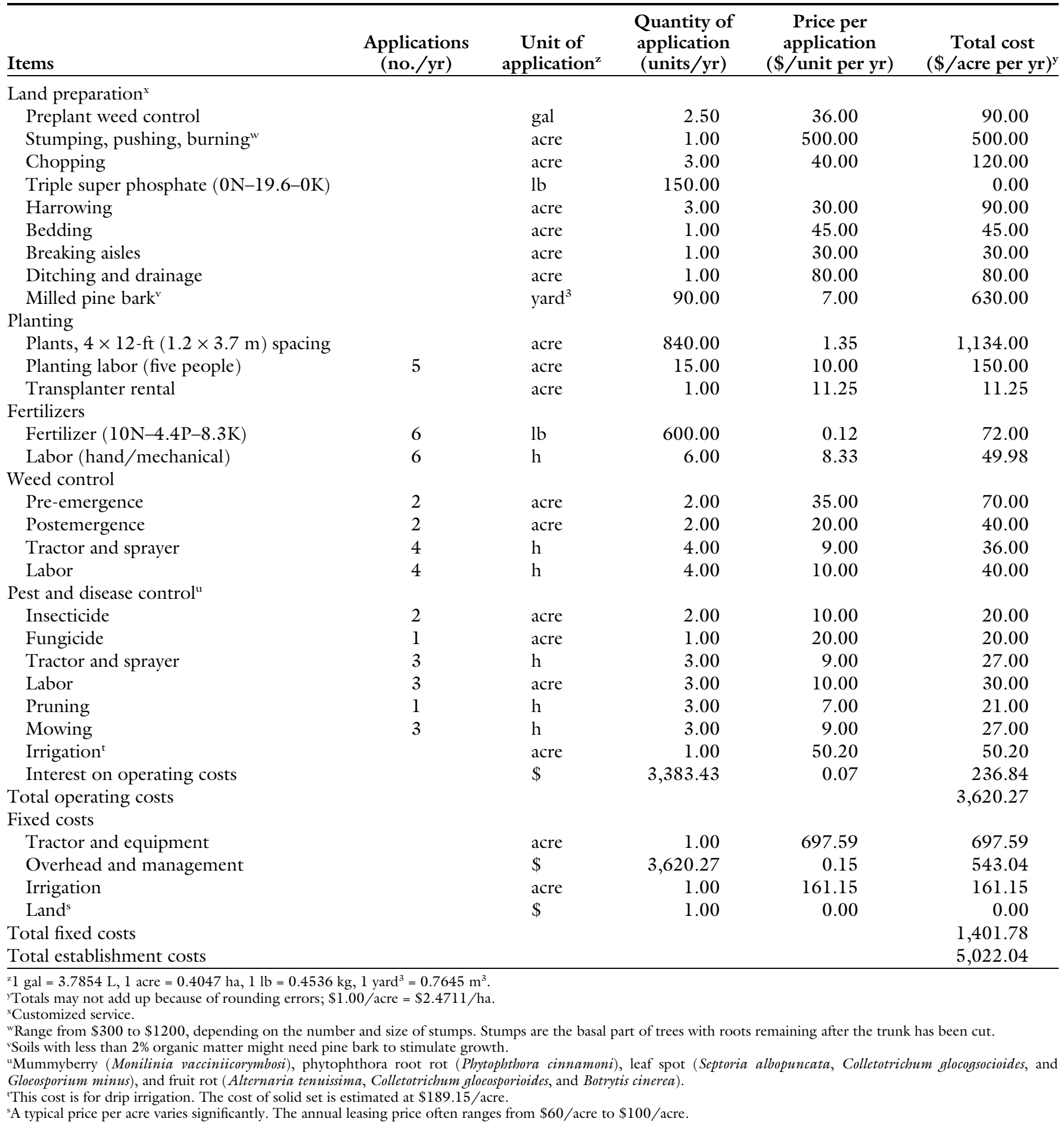


Table 5. Estimated second-year annual establishment and maintenance cost per acre of producing rabbiteye blueberries in Georgia in 2005.

\begin{tabular}{|c|c|c|c|c|c|}
\hline Items & $\begin{array}{c}\text { Applications } \\
\text { (no./yr) }\end{array}$ & $\begin{array}{c}\text { Unit of } \\
\text { application }^{z}\end{array}$ & $\begin{array}{l}\text { Quantity of } \\
\text { application } \\
\text { (units/yr) }\end{array}$ & $\begin{array}{c}\text { Price per } \\
\text { application } \\
(\$ / \text { unit per } y r)\end{array}$ & $\begin{array}{c}\text { Total cost } \\
(\$ / \text { acre per } y r)^{y}\end{array}$ \\
\hline \multicolumn{6}{|l|}{ Operating costs } \\
\hline Fertilizers $(10 \mathrm{~N}-4.4 \mathrm{P}-8.3 \mathrm{~K})$ & 6 & $\mathrm{~h}$ & 600.00 & 0.12 & 72.00 \\
\hline Labor (hand/mechanical) & 6 & $\mathrm{~h}$ & 6.00 & 8.33 & 49.98 \\
\hline Postemergence & 2 & acre & 2.00 & 20.00 & 40.00 \\
\hline Tractor and sprayer & 4 & $\mathrm{~h}$ & 4.00 & 9.00 & 36.00 \\
\hline Labor & 4 & $\mathrm{~h}$ & 4.00 & 10.00 & 40.00 \\
\hline \multicolumn{6}{|l|}{ Pest and disease control ${ }^{\mathrm{x}}$} \\
\hline Insecticide & 2 & acre & 2.00 & 10.00 & 20.00 \\
\hline Fungicide & 1 & acre & 1.00 & 20.00 & 20.00 \\
\hline Irrigation $^{\mathrm{w}}$ & & acre & 1.00 & 50.20 & 50.20 \\
\hline Interest on operating costs & & $\$$ & 524.18 & 0.07 & 36.69 \\
\hline Total operating costs & & & & & 560.87 \\
\hline \multicolumn{6}{|l|}{ Harvesting and marketing costs } \\
\hline Harvesting (manual) & & $\mathrm{lb}$ & 500.00 & 0.65 & 325.00 \\
\hline Custom packing & & & 55.56 & 5.00 & 277.78 \\
\hline Cooling, handling, and brokerage & & $\$$ & 55.56 & 14.00 & 116.67 \\
\hline Total harvesting and marketing costs & & & & & 719.44 \\
\hline Total establishment costs & & & & & $2,223.18$ \\
\hline Less return from receipts & & $\$$ & 500.00 & 1.45 & 725.00 \\
\hline \multicolumn{6}{|l|}{ Fixed costs } \\
\hline Total fixed costs & & & & & 942.87 \\
\hline
\end{tabular}

${ }^{\mathrm{z}} \mathrm{l}$ acre $=0.4047 \mathrm{ha}, \mathrm{l} \mathrm{lb}=0.4536 \mathrm{~kg}$.

yTotal may not add up because of rounding errors; $\$ 1.00 /$ acre $=\$ 2.4711 /$ ha.

${ }^{\mathrm{x}}$ Mummyberry (Monilinia vacciniicorymbosi), phytophthora root rot (Phytophthora cinnamoni), leaf spot (Septoria albopuncata, Colletotrichum glocogsocioides, and Gloeosporium minus), and fruit rot (Alternaria tenuissima, Colletotrichum gloeosporioides, and Botrytis cinerea).

whis cost is for drip irrigation. The cost of solid set is estimated at $\$ 189.15 /$ acre.

"A typical price per acre varies significantly. The annual leasing price often ranges from $\$ 60 /$ acre to $\$ 100 /$ acre.

Quantity discounts for items such as packing supplies were factors that affected price of inputs. The cost estimate in this budget reflects a combination of the current cultural practices in Georgia. The prices were actual prices from vendors around the counties involved in blueberry production, and they excluded quantity discounts.

EsTIMATED ANNUAL TOTAL FIXED MACHINERY COSTS. Fixed machinery cost included sprayers, rotary mower, wagons, tractor, hedger, truck, spreader, mulcher, harrow, and $\mathrm{V}$ blade (Table 1). These costs included the percentage of use for rabbiteye blueberry, the purchase price, salvage value, life span of equipment, depreciation, interest, tax, and insurance. The calculation was based on 25 acres and a $7 \%$ fixed interest rate. Based on this study, the estimated fixed machinery cost was $\$ 698.00 /$ acre.

COMPOUNDED AND RECAPTURED ESTABLISHMENT COSTS. The total establishment costs for years 1, 2, 3 , and 4 were $\$ 5022.04 /$ acre, \$1498.18/acre, \$1621.35/acre, and $\$ 283.66 /$ acre, respectively. These costs were compounded using the University of Georgia Engineering and Economic calculations (Brown and Skinner, 1980). The fixed compounded interest rate was $7 \%$. In our calculation, we used 20 years because we believe that to be the life-span of a well-managed rabbiteye blueberry farm in Georgia. The annual recapture establishment cost was $\$ 2736.11 /$ acre (Table 2).

DRIP IRRIGATION COST. The annual fixed cost of irrigation was estimated at $\$ 161.15 /$ acre and included pipes and fittings, sprinklers, a 6-inch-diameter well that can handle a 300-gal/min pump, motor, installation, and miscellaneous. The variable/operating cost component of the drip irrigation was $\$ 50.20 /$ acre. This calculation was based on 
25 acres, and drip tapes were $12 \times 12$ inch spacing and a 20-horsepower motor. The cost would have been extremely high if only 1 acre was used. For instance, the total annual fixed cost per 25 acres was \$4031.00, whereas the total annual fixed cost was $\$ 211.35 /$ acre (Table 3).

\section{Results and discussion}

The following sections provide a detailed discussion of the estimated establishment and maintenance costs to be incurred in each production year. In this analysis, full production is assumed to be attained on the fourth year of operations.

ESTIMATED ESTABLISHMENT AND MaINTENANCE: Year 1 . The total operating/variable cost of growing rabbiteye blueberry in Georgia was estimated at $\$ 3620.27 /$ acre. The total fixed cost was estimated at $\$ 1401.78 /$ acre. Therefore, the total estimated establishment and maintenance cost for the first year was $\$ 5022.04 /$ acre (Table 4 ). The planting distance was $4 \times 10 \mathrm{ft}$, equivalent to 840 plants/acre costing $\$ 1134.00 /$ acre. Other expensive cost components in land preparation operation were stumping (the remains of a cut-down tree that contains the roots), pushing stumps and large limbs, and burning, which costs $\$ 500.00 /$ acre depending on the number of stumps, chopping, which costs $\$ 120.00$, and milled pine bark, which costs $\$ 630.00$ for 90 yard $^{3}$. Fertility and pre- and postemergence weed control cost were $\$ 307.98 /$ acre (Table 4).

ESTIMATED ESTABLISHMENT AND MaINTENANCE: Year 2. In year two, the cost of weed control was

Table 6. Estimated third-year establishment and maintenance cost per acre of producing rabbiteye blueberries in Georgia in 2005 .

\begin{tabular}{|c|c|c|c|c|c|}
\hline Item & $\begin{array}{c}\text { Applications } \\
\text { (no./yr) }\end{array}$ & $\begin{array}{c}\text { Unit of } \\
\text { application }^{z}\end{array}$ & $\begin{array}{l}\text { Quantity of } \\
\text { application } \\
\text { (units/yr) }\end{array}$ & $\begin{array}{c}\text { Price per } \\
\text { application } \\
(\$ / \text { unit per } y r)\end{array}$ & $\begin{array}{c}\text { Total cost } \\
(\$ / \text { acre per } y r)^{y}\end{array}$ \\
\hline \multicolumn{6}{|l|}{ Fertilizers } \\
\hline Fertilizer $(10 \mathrm{~N}-4.4 \mathrm{P}-8.3 \mathrm{~K}$ banded $)$ & 6 & $\mathrm{lb}$ & 600.00 & 0.12 & 72.00 \\
\hline Labor (hand/mechanical) & 6 & $\mathrm{~h}$ & 6.00 & 8.33 & 49.98 \\
\hline Postemergence & 2 & acre & 2.00 & 20.00 & 40.00 \\
\hline Tractor and sprayer & 4 & $\mathrm{~h}$ & 4.00 & 9.00 & 36.00 \\
\hline Labor & 4 & $\mathrm{~h}$ & 4.00 & 10.00 & 40.00 \\
\hline \multicolumn{6}{|l|}{ Pest and disease control ${ }^{\mathrm{x}}$} \\
\hline Insecticide & 2 & acre & 2.00 & 10.00 & 20.00 \\
\hline Fungicide & 3 & acre & 3.00 & 20.00 & 60.00 \\
\hline Mowing & 3 & $\mathrm{~h}$ & 3.00 & 9.00 & 27.00 \\
\hline Pollination & 1 & acre & 1.00 & 35.00 & 35.00 \\
\hline Irrigation $^{\mathrm{w}}$ & & acre & 1.00 & 50.20 & 50.20 \\
\hline Interest on operating costs & & $\$$ & 616.18 & 0.07 & 43.13 \\
\hline Total operating costs ${ }^{\mathrm{v}}$ & & & & & 659.31 \\
\hline \multicolumn{6}{|l|}{ Harvesting and marketing costs } \\
\hline Harvesting (hand picking) & & $\mathrm{lb}$ & $1,300.00$ & 0.65 & 845.00 \\
\hline Custom packing & & flat & 144.44 & 5.00 & 722.22 \\
\hline Cooling, handling, and brokerage: fresh & & $\$$ & 144.44 & 14.00 & 303.33 \\
\hline Total harvesting and marketing costs & & & & & $1,870.56$ \\
\hline \multicolumn{6}{|l|}{ Fixed costs } \\
\hline Less return from receipts & & $\$$ & $1,287.00$ & 1.45 & $1,866.15$ \\
\hline Total net establishment costs & & & & & $1,621.35$ \\
\hline
\end{tabular}

${ }^{\mathrm{z}} \mathrm{l} \mathrm{lb}=0.4536 \mathrm{~kg}, \mathrm{l}$ acre $=0.4047 \mathrm{ha}, \mathrm{l}$ flat $=1.5 \mathrm{~kg}(3.31 \mathrm{lb})$.

y Totals may not add up because of rounding errors; $\$ 1.00 /$ acre $=\$ 2.4711 / \mathrm{ha}$.

x Mummyberry (Monilinia vacciniicorymbosi), phytophthora root rot (Phytophthora cinnamoni), leaf spot (Septoria albopuncata, Colletotrichum glocogsocioides, and Gloeosporium minus), and fruit rot (Alternaria tenuissima, Colletotrichum gloeosporioides, and Botrytis cinerea).

whis cost is for drip irrigation. The cost of solid set is estimated at $\$ 189.15 /$ acre.

${ }^{v}$ Although year 3 budget is calculated on $100 \%$ fresh, there is a possibility to pick some fruit for frozen. Custom machine pick costs about $\$ 0.13 / \mathrm{lb}(\$ 0.287 / \mathrm{kg})$.

"A typical price per acre varies significantly. The annual easing price often ranges from $\$ 60 /$ acre to $\$ 100 /$ acre. 
$\$ 186.00 /$ acre, at $33 \%$ of total variable cost. The total variable cost was $\$ 560.87 /$ acre, which is 6.5 times lower than year one. It was assumed that $500 \mathrm{lb}$ of blueberries would be harvested in year two.

Total harvesting and marketing costs were $\$ 719.44 /$ acre. This in- cludes harvesting, custom packing, cooling, handling, and brokerage fees. Fixed costs include tractor and equipment, overhead and management,

Table 7. Estimated fourth-year establishment and maintenance cost per acre of producing rabbiteye blueberries in Georgia in 2005.

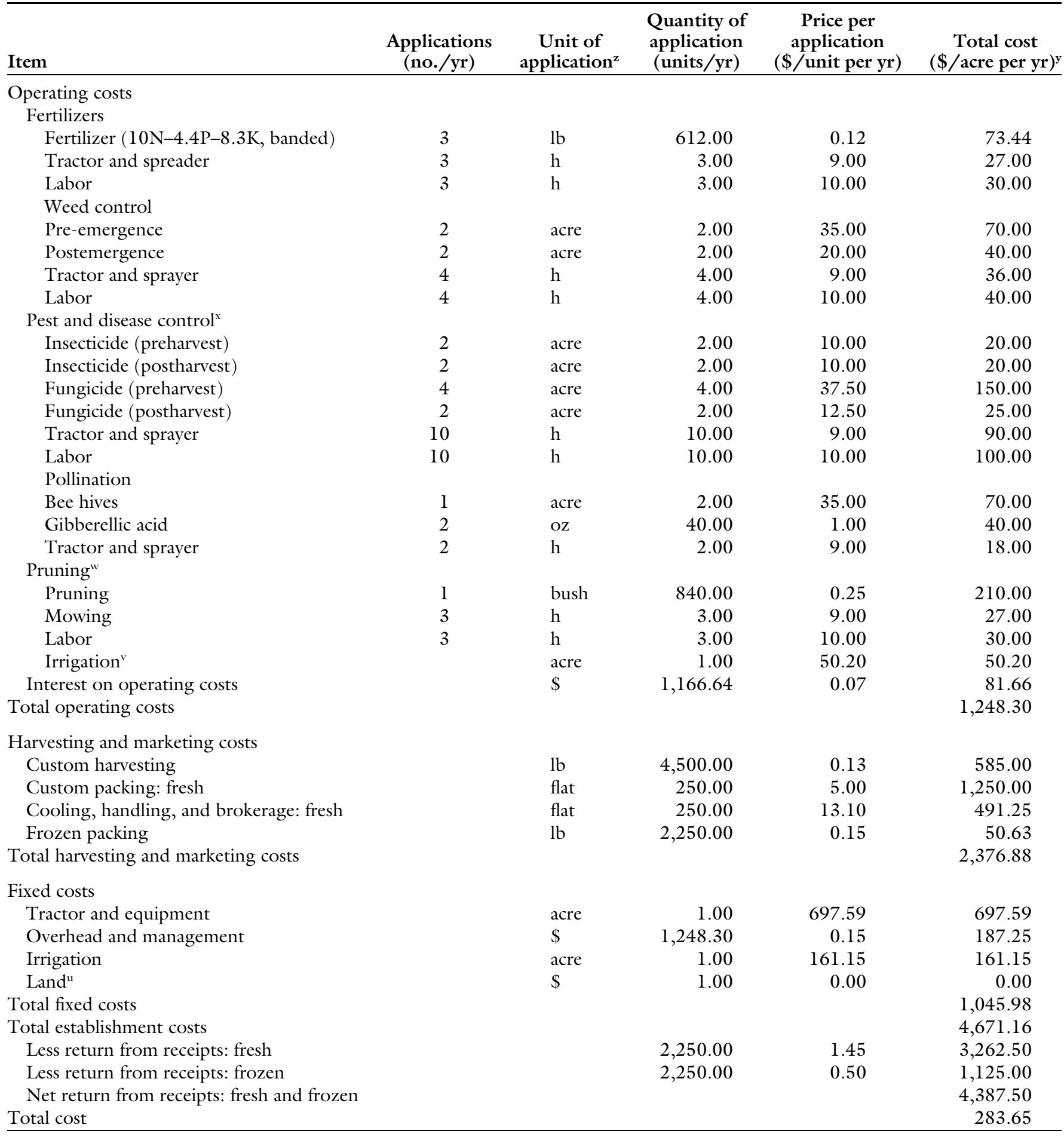

${ }^{\mathrm{z}} \mathrm{l} \mathrm{lb}=0.4536 \mathrm{~kg}, \mathrm{l}$ acre $=0.4047 \mathrm{ha}, \mathrm{l} \mathrm{oz}=28.3495 \mathrm{~g}, \mathrm{l}$ flat $=1.5 \mathrm{~kg}(3.3 \mathrm{l} \mathrm{lb}), \mathrm{l} \mathrm{fl} \mathrm{oz}=29.5735 \mathrm{~mL}$.

yTotals may not add up because of rounding errors; $\$ 1.00 /$ acre $=\$ 2.4711 / \mathrm{ha}$.

x Mummyberry (Monilinia vacciniicorymbosi), phytophthora root rot (Phytophthora cinnamoni), leaf spot (Septoria albopuncata, Colletotrichum glocogsocioides, and Gloeosporium minus), and fruit rot (Alternaria tenuissima, Colletotrichum gloeosporioides, and Botrytis cinerea).

"Mechanical or manual depending on the field.

"This cost is for drip irrigation. The cost of solid set is estimated at $\$ 189.15 /$ acre.

"A typical price per acre varies significantly. The annual leasing price often ranges from $\$ 60 /$ acre to $\$ 100 /$ acre. 
and irrigation, which altogether cost $\$ 942.87 /$ acre. The total cost for year two was $\$ 2223.18 /$ acre. Assuming a return from receipts of $500 \mathrm{lb}$ and a selling price of $\$ 1.45 / \mathrm{lb}$, gross receipts were $\$ 725.00$. This reduced the total establishment cost in year two to $\$ 1498.18$ /acre (Table 5).

ESTIMATED ESTABLISHMENT AND MAINTENANCE: Year 3. In year three, the total variable cost was $\$ 659.31$ / acre. With an estimated quantity of $1300 \mathrm{lb}$ of blueberries, the total harvesting and marketing costs were $\$ 1870.56 /$ acre. This included harvesting, custom packing, cooling, handling, and brokerage fees. Fixed costs included tractor and equipment, overhead and management, and irrigation, which altogether cost $\$ 957.63$ acre. The total cost for year three was $\$ 3489.57 /$ acre. Assuming a return from receipts of $1300 \mathrm{lb}$ and a selling price of $\$ 1.45 / \mathrm{lb}$, gross receipts were $\$ 1866.15 /$ acre. This, $\$ 3489.57$ /acre, equals a net establishment cost of $\$ 1621.35 /$ acre in year three (Table 6).

FULL PRODUCTION COST: YeAR 4. In the fourth year, the rabbiteye blueberry field is assumed to be in full production. The combined mowing and pruning operations was the largest variable cost component, at $\$ 267.00 /$ acre or $21 \%$ of total variable cost. A combined pollination operation cost was $\$ 128.00 /$ acre or $10 \%$ of total variable cost. Total harvesting and marketing costs were $\$ 2376.88$ \% acre. This included harvesting, custom packing (fresh and frozen), cooling, handling, and brokerage fees. Fixed costs include tractor and equipment, overhead and management, and irrigation, which altogether cost $\$ 1045.99$. The total cost/acre during this first full production year was $\$ 4671.17 /$ acre. Assuming a return from receipts of $5000 \mathrm{lb}$ with $50 \%$ sold fresh at $\$ 1.45 / \mathrm{lb}$ and the other $50 \%$ sold frozen at $\$ 0.50 / \mathrm{lb}$, gross receipts of $\$ 4875.00 /$ acre would be generated. This, minus the actual total cost of $\$ 4671.17 /$ acre, equals a net establishment cost of \$283.67/ acre in year four (Table 7).

E CONOMIC RISK-RATED EXPECTED RETURNS. If the expected return or yield for rabbiteye blueberry in Georgia was $5000 \mathrm{lb} /$ acre and the expected price is $\$ 1.45 / \mathrm{lb}$, then the total return will be $\$ 7250.00$ /acre if minus the actual total cost of sold fresh. However, if only $50 \%$ was sold fresh and the remainder was sold as frozen at the price of $\$ 0.05 / \mathrm{lb}$, then the total expected return will be $\$ 4875.00 /$ acre.

ECONOMIC RISK-RATED RETURNS OVER TOTAL COSTS. Table 8 shows the probabilistic chances of obtaining the various calculated risk-rated net return over total costs. The "returns" row of Table 8 depicts six different net return possibilities. According to Westberry et al. (1995), "all net returns are determined from their relationship to the expected net return. They are not determined by multiplying prices and yields then subtracting the total cost. Rather, they reflect the variability of prices and yields. The first 'chances' row shows the estimated frequency of obtaining the above net returns or more. The second 'chances' row shows the estimated frequency of obtaining the above net returns or less."

For instance, there was only an $8 \%$ chance of obtaining $\$ 7772.00 /$ acre of rabbiteye blueberry in Georgia, whereas there was a $5 \%$ chance of earning a negative return of $-\$ 1698.00 /$ acre. Furthermore, there was a $63 \%$ chance of earning the expected \$679.00/acre. The economic risk-rated return over total costs further depicted that the base budgeted net revenue was $\$ 369.00 /$ acre with a $77 \%$ chance of making a profit under Georgia conditions if sold fresh (Table 8).

Sensitivity analysis and ECONOMIC RISK-RATED RETURNS OVER TOTAL COSTS. An economic risk-rated sensitivity analysis over total costs of producing and selling rabbiteye blueberry was conducted to determine the riskiness and profitability margin under five different price and yield levels, respectively. Two price levels, selling 100\% fresh or selling $50 \%$ fresh and $50 \%$ processed were analyzed to determined

Table 8. Economic risk-rated returns over total costs of producing rabbiteye blueberries in Georgia in 2005.

\begin{tabular}{lrrrrrr}
\hline & \multicolumn{2}{c}{ Optimistic } & \multicolumn{2}{c}{ Expected } & \multicolumn{2}{c}{ Pessimistic } \\
\hline Returns $(\$)^{\mathrm{z}}$ & 7,772 & 5,937 & 679 & 944 & -377 & $-1,698$ \\
Chances $(\%)^{\mathrm{y}}$ & 8 & 16 & 63 & 58 & 84 & 1 \\
Chances $(\%)^{\mathrm{x}}$ & 92 & 84 & 37 & 42 & 16 & 5 \\
Chances for profit $=77 \%$ & & \multicolumn{3}{c}{ Base budgeted net revenue $=\$ 369$} & \\
\hline
\end{tabular}

${ }^{2}$ Net return levels.

y The chances of obtaining this level or more.

${ }^{x}$ The chances of obtaining this level or less.

which combination provide optimum financial benefit to the rabbiteye blueberry growers (Table 9). The pessimistic yields used for this analysis were 3,000 and $4,000 \mathrm{lb} / \mathrm{acre}$, and the optimistic yields were 8,000 and $12,000 \mathrm{lb} /$ acre. The five different sensitivity prices used for selling rabbiteye blueberries $100 \%$ fresh were $\$ 1.10 / \mathrm{lb}, \quad \$ 1.25 / \mathrm{lb}, \quad \$ 1.45 / \mathrm{lb}$, $\$ 1.85 / \mathrm{lb}$, and $\$ 2.10 / \mathrm{lb}$. The combined rabbiteye blueberry average prices for selling $50 \%$ fresh and $50 \%$ processed were $\$ 0.68 / \mathrm{lb}, \$ 0.80 / \mathrm{lb}$, $\$ 0.98 / \mathrm{lb}, \$ 1.25 / \mathrm{lb}$, and $\$ 1.43 / \mathrm{lb}$, respectively. Table 9 shows that if a pessimistic yield of $4000 \mathrm{lb} /$ acre were produced and sold all fresh at $\$ 1.85 /$ $\mathrm{lb}$, the grower will obtain a positive return of $\$ 247.00 /$ acre, whereas he/ she would obtain a negative return of $-\$ 765.00 /$ acre if the crop was sold at an average combined $50 \%$ fresh and $50 \%$ processed price of $\$ 1.25 / \mathrm{lb}$. With an optimistic yield of $8000 \mathrm{lb} /$ acre, a positive return of $\$ 4538.00$ / acre would be achieved if sold all fresh at a reduced price of $\$ 1.10 / \mathrm{lb}$ or a return of $\$ 2421.00 /$ acre if sold at an average combined price of $\$ 0.68 / \mathrm{lb}$ for $50 \%$ fresh and $50 \%$ processed.

\section{Conclusion}

The total establishment costs for years $1,2,3$, and 4 were $\$ 5022.04$ / acre, $\$ 2223.18 /$ acre, $\$ 3487.50 /$ acre, and $\$ 1045.98 /$ acre, respectively. The annual recapture establishment cost was $\$ 2736.11 /$ acre. The estimated fixed machinery cost was $\$ 698.00 /$ acre. The annual fixed cost of irrigation/acre was estimated at $\$ 161.15 /$ acre and included pipes and fittings, sprinklers, a 6-inchdiameter well that can handle a 300and miscellaneous.

The preharvest variable cost was $\$ 0.25 / \mathrm{lb}$. The harvesting and marketing cost was estimated at $\$ 0.23 / \mathrm{lb}$, $\mathrm{gal} / \mathrm{min}$ pump, motor, installation,

Hartecthology · July-September 2008 18(3) 
Table 9. Sensitivity analysis and economic risk-rated returns for price and yield over total costs of producing and selling fresh and frozen rabbiteye blueberries in Georgia in 2005.

\begin{tabular}{|c|c|c|c|c|c|c|c|}
\hline $\begin{array}{l}\text { Price fresh } \\
\text { and frozen } \\
(\$ / 1 b)^{z}\end{array}$ & $\begin{array}{c}\text { Pessimistic } \\
\text { yield of } \\
3000 \mathrm{lb} / \text { acre } \\
(\$ / \text { acre })^{\mathrm{y}}\end{array}$ & $\begin{array}{c}\text { Pessimistic } \\
\text { yield of } \\
4000 \mathrm{lb} / \text { acre } \\
(\$ / \text { acre }) \\
\end{array}$ & $\begin{array}{c}\text { Expected } \\
\text { yield of } \\
5000 \mathrm{lb} / \text { acre } \\
(\$ / \text { acre }) \\
\end{array}$ & $\begin{array}{c}\text { Optimistic } \\
\text { yield of } \\
8000 \mathrm{lb} / \text { acre } \\
(\$ / \text { acre }) \\
\end{array}$ & $\begin{array}{c}\text { Optimistic } \\
\text { yield of } \\
12,000 \mathrm{lb} / \text { acre } \\
(\$ / \text { acre })\end{array}$ & $\begin{array}{c}\text { Base } \\
\text { budgeted net } \\
\text { revenue }(\$)^{\mathrm{x}}\end{array}$ & $\begin{array}{l}\text { Chances for } \\
\text { profit }(\%)^{\mathrm{w}}\end{array}$ \\
\hline $0.68^{\mathrm{u}}$ & $-3,280$ & $-2,489$ & -938 & 2,421 & 4,084 & $-3,481$ & 23 \\
\hline $1.25^{\mathrm{v}}$ & $-1,946$ & -765 & 259 & 5,154 & 6,932 & -631 & 64 \\
\hline $0.80^{\mathrm{u}}$ & $-2,871$ & $-1,995$ & -686 & 3,126 & 4,811 & $-2,881$ & 30 \\
\hline $0.98^{\mathrm{u}}$ & $-2,417$ & $-1,419$ & -308 & 4,013 & 5,730 & $-1,981$ & 43 \\
\hline $1.85^{\mathrm{v}}$ & $-1,369$ & 247 & 1,519 & 7,466 & 9,461 & 2,369 & 86 \\
\hline $1.25^{\mathrm{u}}$ & $-1,946$ & -765 & 259 & 5,154 & 6,932 & -631 & 64 \\
\hline $2.10^{\mathrm{v}}$ & $-1,245$ & 565 & 2,044 & 8,432 & 10,555 & 3,619 & 88 \\
\hline $1.43^{\mathrm{u}}$ & $-1,720$ & -413 & 637 & 5,860 & 7,689 & 269 & 76 \\
\hline
\end{tabular}

${ }^{2} \$ 1.00 / \mathrm{lb}=\$ 2.2046 / \mathrm{kg}$.

${ }^{y} 1 \mathrm{lb} /$ acre $=1.1209 \mathrm{~kg} \cdot \mathrm{ha}^{-1}, \$ 1.00 /$ acre $=\$ 2.471 \mathrm{l} / \mathrm{ha}$

xThe percentage chance for profit was calculated based on the expected yield of $5000 \mathrm{lb} /$ acre and the given price.

whe base budgeted net revenue was calculated based on the expected yield of $5000 \mathrm{lb} /$ acre and the going price.

"This row is the price per pound for rabbiteye blueberries sold $100 \%$ fresh.

"This row is the average price per pound for rabbiteye blueberries sold $50 \%$ fresh and $50 \%$ processed.

and the fixed cost was $\$ 0.47 / \mathrm{lb}$. The total budgeted cost amounted to $\$ 0.95 / \mathrm{lb}$. Total operating costs were $\$ 5024.12$ /acre, $\$ 1500.26 /$ acre, $\$ 1623.42 /$ acre, and $\$ 63.91 /$ acre for years $1,2,3$, and 4 , respectively. Harvesting and marketing costs were $\$ 719.44$ /acre, \$1870.55/acre, and $\$ 2642.55$ /acre for years 2,3 , and 4 , respectively. Total fixed costs were $\$ 1403.85$ /acre, $\$ 944.94 /$ acre, $\$ 959.71 /$ acre, and $\$ 1048.06 /$ acre for years $1,2,3$, and 4 , respectively.

In year 4 , combined pruning operation was the largest variable cost component, at $\$ 267.00 /$ acre, equivalent to $21 \%$ of the total variable/ operating cost. Pollination operation contributed to over $10 \%$ of total variable cost, equivalent to $\$ 128.00 /$ acre. Total harvesting and marketing costs were \$2376.88/acre. Fixed machinery cost was $\$ 698.00 /$ acre and included sprayers, rotary mower, wagons, tractor, hedger, truck, spreader, mulcher, harrow, and $\mathrm{V}$ blade.

The annual fixed cost of drip irrigation was estimated at $\$ 161.15$ / acre and included pipes and fittings, tube, a 6-inch-diameter well capable of pumping $300 \mathrm{gal} / \mathrm{min}$, pump, motor, installation and miscellaneous. The variable/operating cost component of the drip irrigation was $\$ 50.20 /$ acre, and the total annual costs (i.e., total operating cost plus total annual fixed costs) were $\$ 211.35 /$ acre.
The expected yield for rabbiteye blueberry in Georgia was $5,000 \mathrm{lb} /$ acre. The risk-rated net returns showed that there was only an $8 \%$ chance of obtaining $\$ 7772.00 /$ acre of rabbiteye blueberry in Georgia, whereas there was a $16 \%$ chance of earning a negative return of $-\$ 377.00 /$ acre. Furthermore, there was a $63 \%$ chance of earning the expected $\$ 679.00 /$ acre. The riskrated returns over total costs further depicted that the base budgeted net revenue was $\$ 369.00 /$ acre with a $77 \%$ chance of making a profit under Georgia conditions.

An economic risk-rated sensitivity analysis over the total costs of producing and selling rabbiteye blueberry was conducted to determine the riskiness and profitability margin under five different price and yield levels. The results showed that if a pessimistic yield of $4000 \mathrm{lb} /$ acre were produced and sold all fresh at \$1.85/ $\mathrm{lb}$, then growers will obtain a positive return of $\$ 247.00 /$ acre, whereas he/ she would obtain a negative return of $-\$ 765.00 /$ acre if the crop was sold at an average combined $50 \%$ fresh and $50 \%$ processed price of $\$ 1.25 / \mathrm{lb}$. With an optimistic yield of $8000 \mathrm{lb} /$ acre, a positive return of $\$ 4538.00 /$ acre would be achieved if sold all fresh. A reduced price of $\$ 1.10 / \mathrm{lb}$ or a return of $\$ 2421.00 /$ acre would be achieved if sold at an averaged combined price of $\$ 0.68 / \mathrm{lb}$ for $50 \%$ fresh and $50 \%$ processed.

\section{Literature cited}

Abbe, D.S. and C.S. Messer. 2004. Agricultural prices. Official Georgia estimate: Blueberries. Census of agriculture Georgia profiles. 4 Nov. 2004. <http://www.nass. usda.gov/ga/cropests/bluebery.txt>.

Brigham, E.F. 1982. Financial management theory and practice. 3rd ed. Dryden Press, New York.

Brown, E. and R.E. Skinner. 1980. Economic analysis of selected sprinkler irrigation systems. Univ. Georgia Coop. Ext. Serv. Bul. 731 .

Cline, B. and M. Mainland. 1999. Blueberry production recommendations and costs introduction. Proc. 33rd Annual Open House North Carolina Blueberry Council, Elizabethtown, NC. p. 9-12.

Florkowski, W.J. 2004. Commercial blueberry inventory and prospectus. Univ. Georgia 2002 Res. Rpt. No. 693.

Fonsah, E.G., G. Krewer, K. Harrison, and M. Bruorton. 2007. Risk-rated economic return analysis for southern high bush blueberries in soil in Georgia. HortTechnology 17:571-579.

Krewer, G. and D.S. NeSmith. 2002. The Georgia blueberry industry: Its history, present state and potential for development in the next decade. Acta Hort. 574:101-106.

Lisec, B., T. Cross, and B. Strik. 1995. Blueberry economics: The costs of establishing and producing blueberries in the Willamette Valley, Oregon State Univ. Ext. Serv. EM 8526. 
Payne, J.A., A.A. Amis, R.J. Beshear, R.J. Gagne, D.L. Horton, and P.M. Lyrene. 1993. "New" rabbiteye blueberry insects: Maggots, midges, thrips, and root weevils, p. 37-38. In: G. Krewer (ed.). Proc. 6th Biennial Southeast Blueberry Conf., Tifton, GA.

Pollack, S. and S. Perez. 2003. Fruit and tree nuts situation and outlook yearbook.
Market Trade Economic Div., Economic Res. Serv., U.S. Dept. Agr., October, FTS-2003.

Smith, B.J. 2003. Susceptibility of southern highbush blueberry cultivars to phytophthora root rot and botryosphaeria stem bight, p. 18-27. In: G. Krewer (ed.). Proc. Georgia-outh Carolina Blueberry Conf., Savannah, GA.
Steck, G.J. and J.A. Payne. 1993. Blueberry maggot, Rhagoletis mendax (Diptera: Tephritidae). Florida Dept. Agr. Consumer Serv., Div. Plant Ind., Entomol. Circ. No. 358.

Westberry, G.O., W.O. Mizelle, D. Stanaland, and G. Krewer. 1995. Economic analysis of producing commercial blueberries. Univ. Georgia. Ag-Econ. Bul. 95-040. 